fournal of Medical Genetics (1976). 13, 164-165.

\section{Progeria in twins}

Sir,

Viegas, Souza, and Salzano (1974) reported identical twins with progeria, a most important observation. However, they implicate autosomal recessive inheritance for progeria, despite the fact that the great majority of patients with progeria represent a sporadic occurrence in an otherwise normal family (DeBusk, 1972). Our recent data (Jones et al, 1975) showed older paternal age, a known factor associated with fresh gene mutation for autosomal dominant disorders, in fathers of progeria individuals. The mean paternal age for 18 such fathers was 34.1 years. The father of the Viegas et al patient was 38 years at the birth of these affected identical twins. Though genetic heterogeneity may exist for the phenotype of progeria, the present data favour the concept that most cases are the result of a single fresh mutant gene aetiology.

$$
\text { Yours, etc, }
$$

David W. Smith

Dysmorphology Unit, Dept. of Pediatrics, University of Washington Medical School, Seattle, Washington 98195, USA

\section{REFERENCES}

DeBusk, F. L. (1972). The Hutchinson-Gilford progeria syndrome. Fournal of Pediatrics, 80, 697.

Jones, K. L., Smith, D. W., Harvey, M. A. S., Hall, B. D., and Quan, L. (1975). Older paternal age and fresh gene mutation: data on additional disorders. Fournal of Pediatrics, 86, 84-88.

Viegas, J., Souza, P. L. R., and Salzano, F. M. (1974). Progeria in twins. Fournal of Medical Genetics, 11, 384-386.

\section{Chromosome abnormalities in Southwest American Indian patients}

Sir,

As authors such as Thorburn (1971) and Hungerford (1963) have shown, increasing interest has been shown in the occurrence and incidence of chromosomal aberrations in different populations and racial groups. However, there are few data from many populations. For example, Cornu et al's (1968) reported cases of trisomy syndromes have dealt mainly with children of Caucasian ancestry, though frequency of Down's syndrome has also been estimated for Negroes and Orientals by Wagner (1962) and Lejeune (1964). The need for further genetic evaluation of varied populations is indicated, since the distribution of chromosomal abnormalities such as trisomy syndromes appears to differ with respect to geography (space) and time, as Day (1966) has shown. The purpose of this report is to present additional data of this nature obtained from American Indian patients from New Mexico and Arizona. These groups are highly endogamous as a result of inbreeding according to Hewitt and Stewart (1970), and consequently form population isolates of special interest. We were unable to find any reports describing the occurrence of any type of chromosomal aberration among similar Indian groups, and, in particular, with reference to Down's syndrome.

Chromosome analysis was performed on an Indian group of 42 patients by a modified method of Moorhead et al (1960), and compared against a control group of 270 Caucasian patients. Both groups represent patients referred to the Cytogenetics Laboratory at the University of New Mexico School of Medicine over a period of 5

TABLE

COMPARISON OF CHROMOSOMAL ABNORMALITIES IN AMERICAN INDIAN AND CAUCASIAN PATIENT GROUPS

\begin{tabular}{|c|c|c|c|c|c|c|c|c|c|}
\hline \multirow{2}{*}{$\begin{array}{l}\text { Patient or Karyotype } \\
\text { Classification }\end{array}$} & \multicolumn{2}{|c|}{ Caucasian Totals } & \multicolumn{2}{|c|}{ Indian Totals } & \multicolumn{5}{|c|}{ No. of Cases } \\
\hline & $\begin{array}{l}\text { No. of } \\
\text { Cases }\end{array}$ & $\%$ Total & $\begin{array}{l}\text { No. of } \\
\text { Cases }\end{array}$ & $\%$ Total & Navajo & Pueblo & Zuni & Apache & $\begin{array}{c}\text { Tribe } \\
\text { Unknown }\end{array}$ \\
\hline $\begin{array}{l}\text { Normal } \\
\text { Total chromosomal } \\
\text { abnormalities }\end{array}$ & $\begin{array}{l}156 \\
114\end{array}$ & $\begin{array}{l}58 \\
42\end{array}$ & $\begin{array}{l}26 \\
16\end{array}$ & $\begin{array}{l}62 \\
38\end{array}$ & $\begin{array}{r}10 \\
8\end{array}$ & $\begin{array}{r}10 \\
3\end{array}$ & $\begin{array}{l}1 \\
1\end{array}$ & $\begin{array}{l}1 \\
1\end{array}$ & $\begin{array}{l}4 \\
3\end{array}$ \\
\hline $\begin{array}{l}\text { Trisomy G } \\
\text { Trisomy D } \\
\text { Trisomy E } \\
\text { Klinefelter's (XXY) } \\
\text { 'Superfemale' (XXX) } \\
\text { Turner's (XO) } \\
\text { Testicular feminization } \\
\text { (phenotypic female, XY) } \\
\text { Marker chromosome } \\
\text { Philadelphia chromosome }\end{array}$ & $\begin{array}{r}56 \\
2 \\
3 \\
12 \\
6 \\
-5 \\
15\end{array}$ & $\begin{array}{c}21 \\
0.9 \\
1.4 \\
5.4 \\
2.7 \\
\overline{2.3} \\
6.8\end{array}$ & $\begin{array}{l}8 \\
1 \\
1 \\
1 \\
1 \\
1 \\
1 \\
1 \\
1\end{array}$ & $\begin{array}{l}20 \\
2.5 \\
2.5 \\
2.5 \\
2.5 \\
2.5 \\
2.5 \\
2.5 \\
2.5\end{array}$ & $\begin{array}{l}3 \\
1 \\
1 \\
1 \\
1 \\
1\end{array}$ & 2 & 1 & 1 & 2 \\
\hline
\end{tabular}


years as a result of our standard procedures for patients with suspected chromosomal abnormalities. Patients were classified as Indian by the Bureau of Indian Affairs of the Public Health Service using standard Bureau of Indian Affairs criteria.

The number and percentage of patients in each racial group that had a specific chromosomal aberration are shown in the Table. The Indian group total was broken down into tribal groups when known. Similar chromosomal abnormalities appeared in both racial groups.

The $\chi^{2}$ test was used to evaluate differences in the occurrence of chromosomal aberrations between the two groups. No significant differences were noted in the incidence of either total aberrations $(0.6<p<0.7)$ or specifically of trisomy $\mathrm{G}(0.8<\mathrm{p}<0.9)$. For these factors, both the Indian and Caucasian patient groups can be considered as samples from the same population. This similarity suggests the possibility that normal Indian and Caucasian populations may have the same incidence of total and particular aberrations. For this reason, further study on normal populations is indicated, particularly consecutive American Indian newborn studies, etc.

Meaningful conclusions from this small study are not proposed because the groups studied may have been chosen in a biased manner (we think not, but we did not investigate either report or control group sampling bias) and the number of patients is small. In this part of the world, many claims by uninformed physicians are made about the great differences in cytogenetic disorders between American Indians and others. Chromosomal abnormalities and syndromes do occur in these groups.
No inference about incidence, frequency, or sampling is intended.

$$
\text { Yours, etc, }
$$

Thomas S. McConnell, M.D., Robert E. Foreman, and Nancy K. Bergren

Department of Pathology,

The University of New Mexico,

School of Medicine,

Albuquerque, New Mexico 87131, $U S A$

REFERENCES

Cornu, G., Lintermans, J. P., Van Der Berghe, H., and Eeckels, R. (1968). Trisomy $17 / 18$ and trisomy $13 / 15$ in the African child. fournal of Tropical Medicine and Hygiene, 71, 105-109.

Day, R. (1966). The epidemiology of chromosomal aberrations. American fournal of Human Genetics, 18, 70-80.

Hewitt, D. and Stewart, A. (1970). Relevance of the twin data to intrauterine selection: special care of childhood cancer. Acta Geneticae Medicae et Gemellologiae, 19, 83-86.

Hungerford, D. A. (1963). Human cytogenetics and its relation to anthropology. American fournal of Physical Anthropology, 21, 404.

Lejeune, J. (1964). The 21 trisomy-current stage of chromosomal research. Progress in Medical Genetics, 3, 144-176.

Moorhead, P. S., Nowell, D. C., Mellman, W. J., Battips, D. M., and Hungerford, D. A. (1960). Chromosome preparations of leukocytes cultured from human peripheral blood. Experimental Cell Research, 20, 613-616.

Thorburn, M. J. (1971). In Correspondence. Fournal of Medical Genetics, 8, 250.

Wagner, H. R. (1962). Mongolism in orientals. American fournal of Diseases of Children, 103, 706-714. 